\title{
CHARACTERISTICS AND HOUSEHOLD TOXIC HAZARDOUS WASTE GENERATION BASED ON ECONOMIC STATUS AND TOPOGRAPHIC REGIONS IN SEMARANG CITY, INDONESIA
}

\author{
Elanda Fikri', P. Purwanto ${ }^{2}$, Henna Rya Sunoko Abdurachim ${ }^{3}$ \\ 1 Department of Environmental Health, Bandung Health Polytechnic, Cimahi Utara, 40514, Doctorate Program \\ of Environmental Studies, Diponegoro University, Semarang, Indonesia, 50241,e-mail:elandafikri@yahoo.com \\ 2 Department of Chemical Engineering, Faculty of Engineering, Diponegoro University, Semarang, Indonesia, \\ 50241, e-mail: p.purwanto@gmail.com \\ 3 Faculty of Medicine, Diponegoro University, Semarang, Indonesia, 50241 e-mail: hennarsunoko@gmail.com
}

Received: 2017.06 .02

Accepted: 2017.08.01

Published: 2017.09.01

\begin{abstract}
Hazardous and toxic waste are not only produced by industry, but also by households. But in fact, the household activities also produce Household Toxic and Hazardous Waste (HTHW). Considering the potential of the impact of HTHW to worsening environment quality, the effort of HTHW management must have been started well. One important aspect in the management strategy is to determine the characteristics and the HTHW generation. The method used to determine the characteristics HTHW refers to SNI 19-2454-2002, while the calculation of HTHW generation refers to the SNI 19-3694-1994 calculated based on weight and volume. Sampling was conducted in four districts of Semarang (Pedurungan, Semarang Barat, Semarang Utara and Banyumanik). The samples used in this study were 400 families that were selected based on the proportion of Slovin Formula. Data analysis performed using Analysis of Variance (ANOVA) and Kruskal-Walis test $(\alpha=0.05)$. The largest characteristic of HTHW in Semarang City is infectious (79\%), further Poisonous (13\%), Combustible (6\%) and Corrosive (2\%). While HTHW generation is $0.01 \mathrm{~kg} /$ person/day (5.1\% MSW). Statistical test result showed there was a significant difference (p-value : 0.001$)$ between HTHW generation based on economic level, but there was no significant difference ( $p$-value :0.442) between HTHW characteristics in Semarang city. The level of education, occupation, income level and lifestyle may become potential factors in differentiating the characteristics and HTHW generation in Semarang city.
\end{abstract}

Keywords: households toxic, hazardous waste, economic level, generation, topographic regions

\section{INTRODUCTION}

The escalation of society needs will increase the waste produced. It is included in household toxic hazardous waste (HTHW). Nowadays, the industrial sector is considered as the hazardous and toxic material resource. In fact, the household activities also produce HTHW. Waste disposal in the society settlement is not much. Due to huge population and there is no special treatment, it will seriously cause danger for the environment and human health.
Generally, people in cities $(85,3 \%)$ mix all components of household waste, including HTHW. Many people do not know that household activities can produce dangerous waste and endanger health and surrounding environment (Fikri et al., 2014; Fikri et al., 2016). Although the existence household hazardous waste in the waste appearance from city people is relatively small, but with the increasing population, the amount of waste generated will also increase.

The impact of HTHW is accumulated in the water and soil annually. For example, in the re- 
search conducted by Tuthill et al (1987) dan Ololade et al (2009) the sample shows result containing $\mathrm{Pb}, \mathrm{Ni}, \mathrm{Cd}$ and also the increase of physic parameter concentration and chemical such as $\mathrm{pH}$, turbidity, conductivity and phosphate (Tuthill et al., 1987; Ololade et al., 2009). Considering the potential of the impact of HTHW, it would require proper management. One aspect that is important as the first step is to develop guidelines and HTHW management strategy is to determine the characteristics and HTHW generation.

\section{MATERIAL AND METHODS}

\section{Research Sites}

The study was conducted in the Semarang City (Indonesia), Semarang lies between $6^{\circ} 50^{\prime}-7^{\circ} 10^{\prime}$ of south latitude and line $109^{\circ} 35-110^{\circ} 50^{\prime}$ of east longitude. The west border is Kendal Regency, the east border is Demak Regency, the south border is Semarang Regency, and the north is Java Ocean with the length of $13,6 \mathrm{~km}$.

\section{The Sample of the Research}

The calculation of the total of the research sample was calculated by using Slovin formula (Sevila, 1990; Rivera, 2007; Ryan, 2013). Based on the calculation result, there are 400 families which are used as the sample of the research. The next step is determining the sample of the location in Semarang City by using Stratified Proportional Sampling Method (based on economy level and the geography condition of Semarang City). The proportion of the number of respondent which will be used as the sample is presented in Table 1.

\section{Primary Data Collection}

\section{HTHW Generation}

HTHW generation is based on Indonesian National Standard (SNI 19-3694-1994) and was conducted for 32 consecutive days for four districts in the Semarang City.

\section{HTHW characteristics}

Sampling was done by the separation of organic waste and HTHW. After the separation, followed by identification of characteristic/composition HTHW based attachment Indonesian National Standard SNI 19-2454-2002.

\section{Data Analysis}

Data analysis using ANOVA with 95\% confidence level $(\alpha=5 \%)$ using SPSS software version 20 .

\section{RESULTS AND DISCUSSION}

\section{HTHW Generation}

HTHW generation in Semarang City is 0.01 $\mathrm{kg} /$ person/day (5.1\% MSW) or $0.0591 \mathrm{l} /$ person/ day $(3.9 \% \mathrm{MSW})$. Estimated HTHW generation in 2014 reach 16,003 tons/day or $94,415 \mathrm{~m}^{3} /$ day. Projection result in the next 4 years (2019) is estimated to reach minimum 17.1 ton/day or $101 \mathrm{~m}^{3} /$ day. Moreover, this trend will increase by 18.5 ton/day each year or $109.4 \mathrm{~m}^{3} /$ day in 2025 (linear equations : $y=1,278 x+82,00$ (volume), $y=0,216 x+13,89$ (weight). .

HTHW generation based on economic strata showed a significant difference. The upper economic strata groups produce HTHW of 0,014 $\mathrm{kg} /$ person/day $(7.10 \% \mathrm{MSW})$, middle economic strata $0,008 \mathrm{~kg} / \mathrm{person} /$ day $(3.48 \% \mathrm{MSW})$ and lower economic strata $0,003 \mathrm{~kg} /$ person/day (3.34\% MSW). Total generation HTHW on upper economic strata 2.04 times higher than the middle economic strata and 2.13 times higher compared to the lower economic strata. The descriptive difference was based on ANOVA test with pvalue each 0.001 and 0.015 . Therefore, the result showed the significant difference ( $p$-value $<0.05$ ) between generations HTHW based on economic level in Semarang City.

\section{HTHW Characteristics}

Table 2 shows the characteristics of HTHW in Semarang divided into 4 types: corrosive, combustible, poisonous and infectious. Sampling results to identify the characteristics of HTHW in Semarang city indicate that HTHW generation: corrosive $(0.0002 \mathrm{~kg} /$ person/day), combustible $(0.0006$ $\mathrm{kg} /$ person/day), poisonous (0.0018 kg/person/ day) and infectious ( $0.0074 \mathrm{~kg} /$ person/day).

Based on the descriptive analysis in Figure 4, the domination characteristics of HTHW based on the measurement of weight scale was infectious group with $79 \%$, and then poisonous group $13 \%$, combustible $6 \%$, and the last corrosive with $2 \%$ percentage.

From the sampling result there should be a serious concern to manage infectious group of 


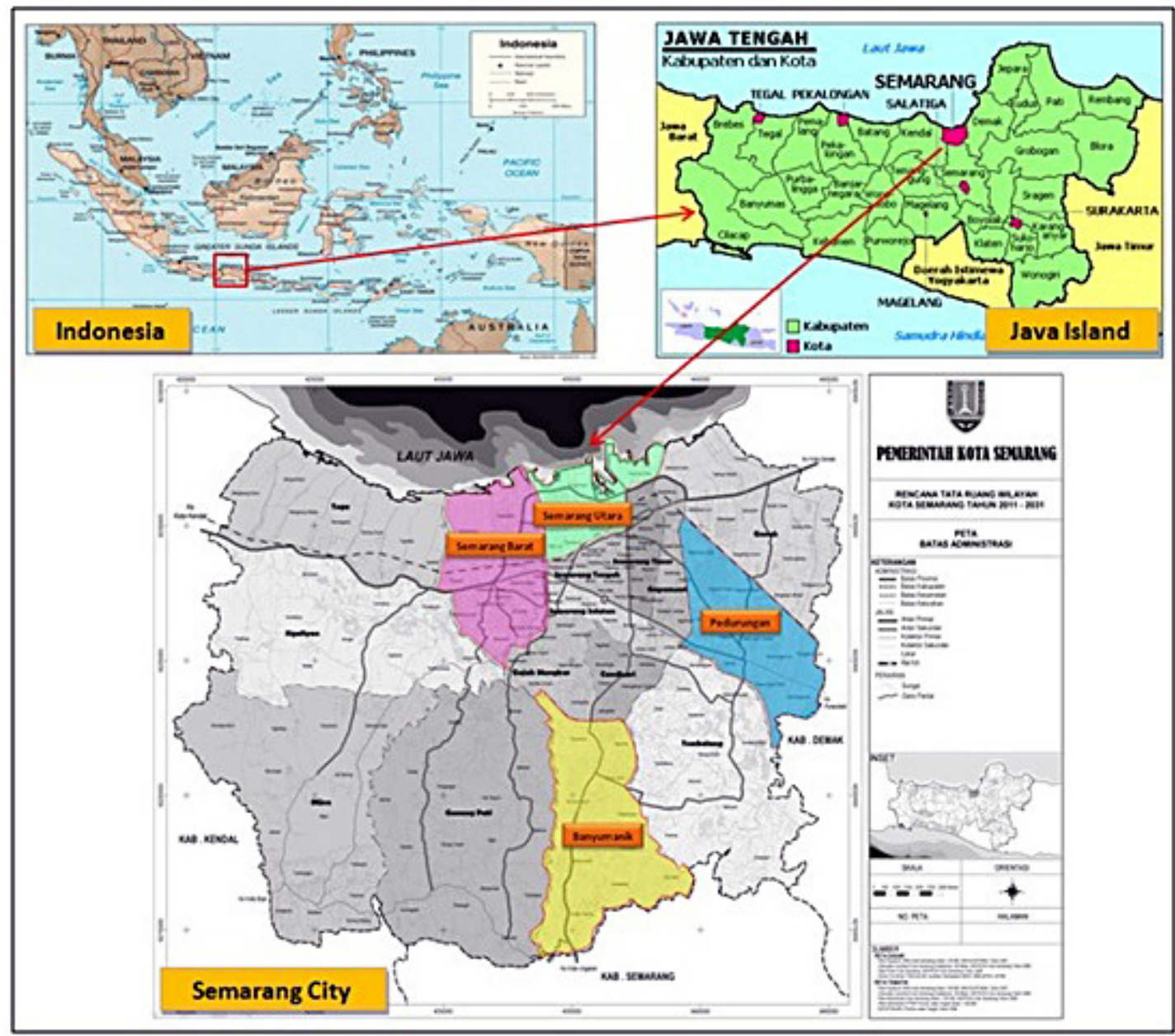

Figure 1. Research Sites

Table 1. The location of the research and the amount of needed sample according to each sub-district

\begin{tabular}{|l|c|c|c|c|c|c|}
\hline \multicolumn{1}{|c|}{ Sub-district } & House condition & Economy level & Geographic area & Total family & $(\%)$ & Sample \\
\hline Pedurungan & permanent & upper & up town & 48.859 & 28.11 & 113 \\
\hline Semarang Barat & semi-permanent & middle & up town & 53.448 & 30.75 & 123 \\
\hline Semarang Utara & non-permanent & lower & up town & 31.854 & 18.33 & 73 \\
\hline Banyumanik & - & - & down town & 39.650 & 22.81 & 91 \\
\hline \multicolumn{7}{|c|}{ Total } \\
\hline
\end{tabular}

HTHW. Until now, there is no stated regulation including in SNI 19-2454-2002. Revision is needed in that SNI. In this research, HTHW infectious group was included in the analyses based on the effect on health (infection spreading) that would be caused and the degrading of environment quality. This background was supported by the categorization conducted by Delgado et al., (2007) and Jin et al., (2006) (Delgado et al., 2007; Jin et al., 2006). According to Delgado et al. (2007) classification HTHW there are 8 categories, one of which is that it can cause infection such as: rubber gloves, syringes, condoms, bandages and gauze bandages, while Jin et al (2006) confirm the statement "waste segregation at the source itself is extremely important as municipal solid waste turn hazardous when mixed with hazardous waste such as paint, dyes, batteries and human excreta". So it is clear that the addition of one (1) characteristics/category HTHW as "infectious" is one that is relevant, both from a quantitative and health impacts and environmental degradation.

Based on the sampling results of the 400 families within 32 days in the city, HTHW with the characteristics of "infectious" the most dominant and commonly found types of diapers, bandages, gauze, some condoms, and plabot former 


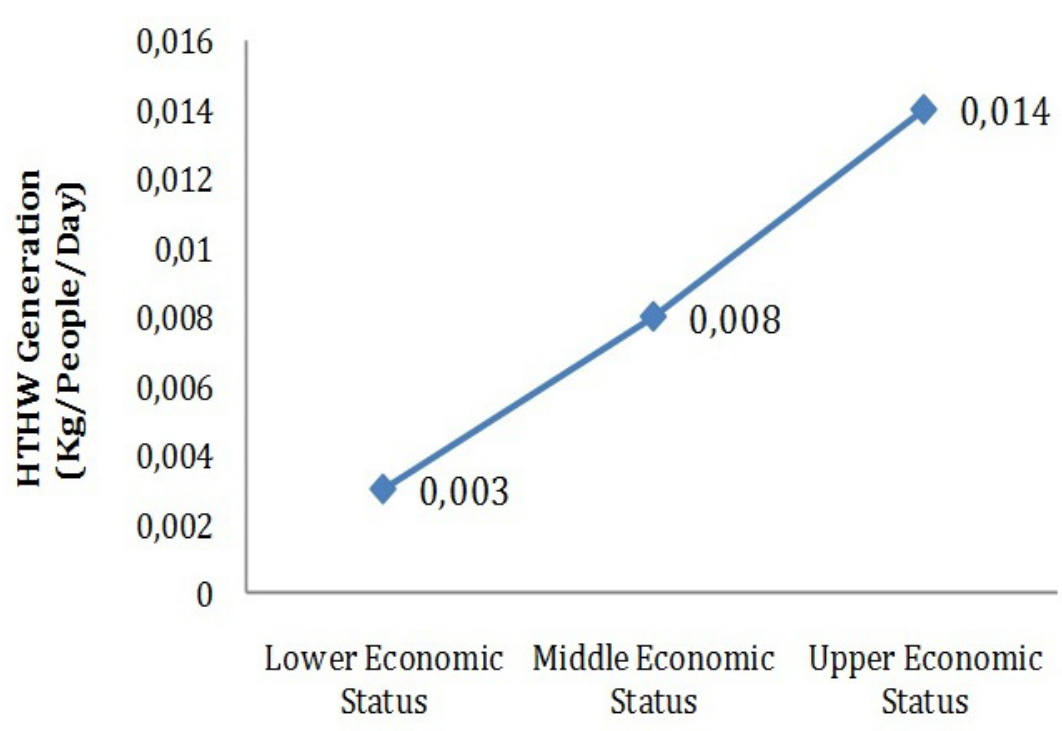

Figure 2. Comparison HTHW Generation Based Economic Strata

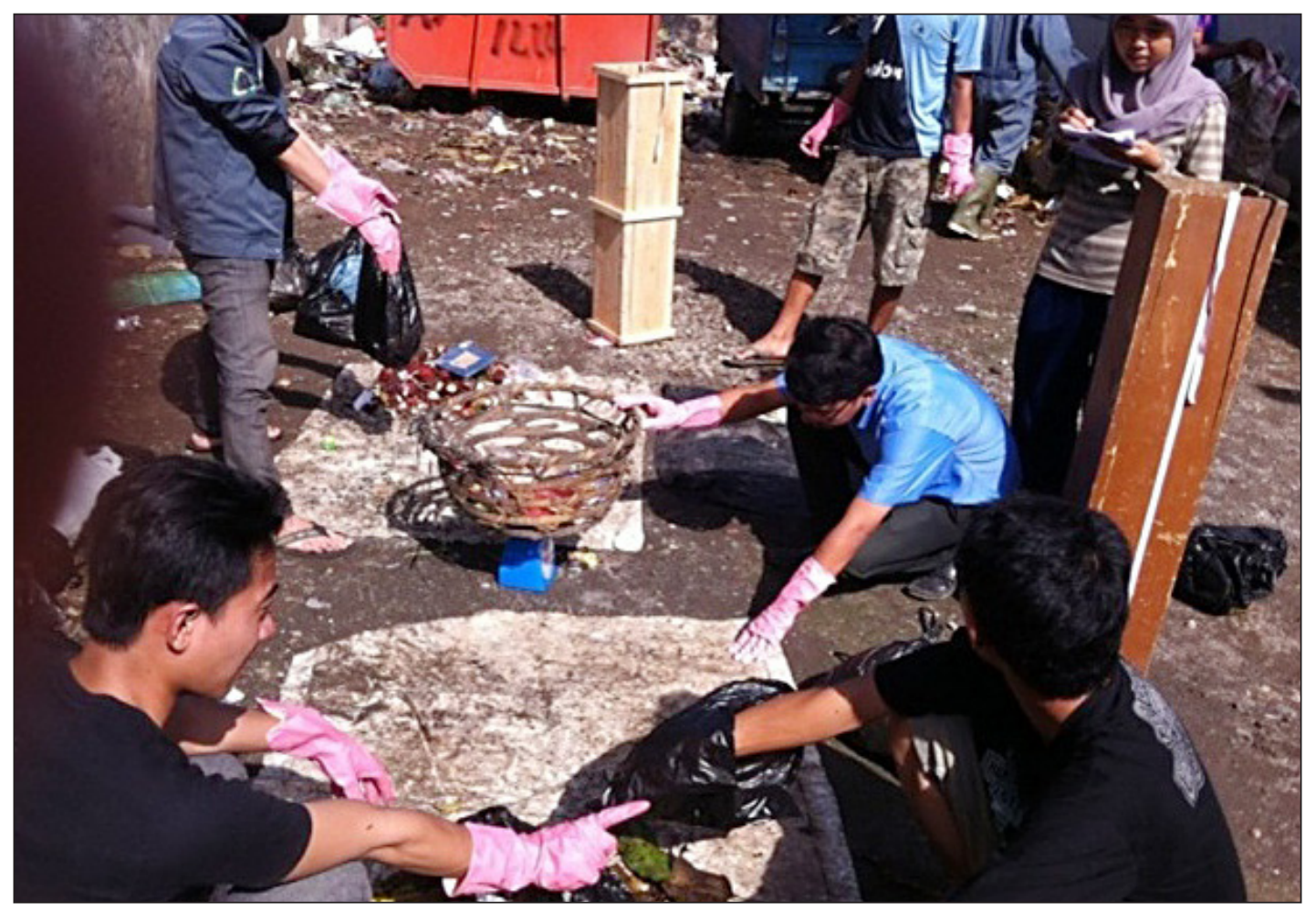

Figure 3. Calculations HTHW Generation in the study site

infusion. The diversity of the characteristics of HTHW in Pedurungan found in the district which is a region on a sample group of economic strata.

Different characteristics HTHW based economic strata, do not mean the same with different characteristics based on HTHW topography. The statistical results using Kruskal-Walis test showed no differences in the characteristics HTHW based topographic regions (p-value 0.442). So that the test results can be interpreted to have simi- lar characteristics to HTHW based topographic regions in Semarang.

\section{Comparison with Other Countries}

Previous research found in seven (7) different countries, including: India, Vietnam, Switzerland, Mexico, Greece, the UK and Hungary. For example, research conducted by Lakshmikantha \& Lakshminarasimaiah (2007) in the State of 
Tabel 2. Examples of HTHW in Semarang city

\begin{tabular}{|c|c|c|c|}
\hline Corrosive & Combustible & Poisonous & Infectious \\
\hline $\begin{array}{l}\text { - } \text { Bleach } \\
\text { - Fabric softener } \\
\text { - Household cleaners } \\
\text { - Accu } \\
\text { - Batteries (auto, household, } \\
\text { \& rechargeable) } \\
\text { - Pool chemicals }\end{array}$ & $\begin{array}{l}\text { - Motor oil and oil filters } \\
\text { - Thiner } \\
\text { - Solvent } \\
\text { - Aerosol cans } \\
\text { - Catridge } \\
\text { - Nail polish and removers } \\
\text { - Glue }\end{array}$ & $\begin{array}{l}\text { - Pesticides } \\
\text { - } \text { Fluorescent lamps - including } \\
\text { tubes and compact fluorescent } \\
\text { lamps } \\
\text { - Parfume } \\
\text { - Fertilizers } \\
\text { - Pharmaceuticals } \\
\text { - Rat poison } \\
\text { - Detergent } \\
\text { - Deodorant } \\
\text { - Cosmetics }\end{array}$ & $\begin{array}{l}\text { - } \text { Diapers } \\
\text { - Bandage } \\
\text { - Condom }\end{array}$ \\
\hline
\end{tabular}

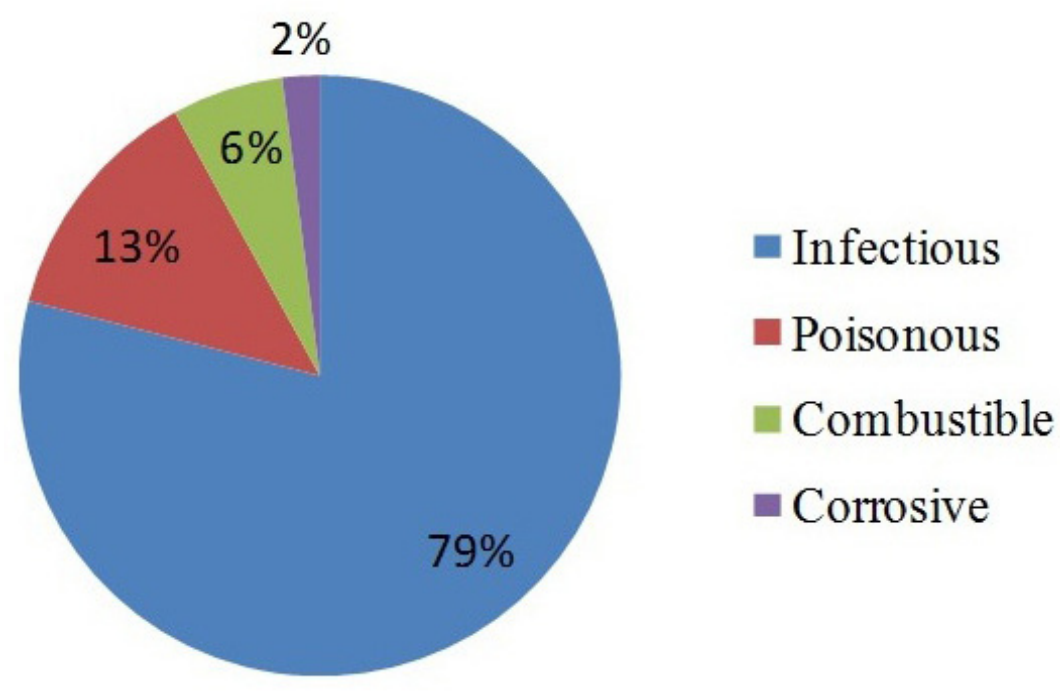

Figure 4. Comparison of the characteristics of HTHW

Karnataka (India) (Lakshmikantha, 2007), which reported that the results of sampling HTHW in the City of $0.005 \mathrm{~kg} /$ person/day (300 tons/day or $0.9 \%$ MSW ). Results of another study, reported by Thanh et al. (2010) based on the results of the sampling in the Mekong (Vietnam) were reported in the city HTHW generation is smaller, and only reaches $0.00053 \mathrm{~kg} /$ person/day $(0.2 \%$ MSW) (Thanh et al., 2010). Other studies have also reported that studies are not much different, as in Switzerland which reported its HTHW generation of $2 \mathrm{~kg} /$ person/year in 2001 with a percentage $(0.5 \%$ of MSW), which means lower than generation HTHW in Semarang per year, which reached $3.65 \mathrm{~kg} /$ person/year with a percentage (5.1\% MSW).

Research conducted by Otoniel et al (2008) in Morelia (Mexico) shows the same thing also that generation of HTHW in the city of Morelia (Mexico) is estimated to be 7.1 tonnes/day with a percentage of $1.6 \%$ of the total domestic waste (Otoniel et al., 2008). While in Semarang in 2014 is estimated to reach 16.0 tons/day HTHW with a percentage of $5.1 \%$ of the total domestic waste.

Other studies have shown different results with this research. Research conducted by Zotos et al (2009) in Greece who reported HTHW generation of 7,000 tons per year (Zotos et al., 2009), further research reported by Otoniel et al (2008) on HTHW generation in the UK amounted to 250,000 tons HTHW / year with a percentage $0.9 \%$ HTHW in MSW with the largest HTHW category is aerosol $(26 \%)$, paint $(17 \%)$, oil $(15 \%)$, batteries (14\%) and bleach (10\%). Different also reported from Hungary in 2002, there were 17,000 tons of HTHW or about $0.7 \%$ of $\mathrm{MSW}$ (Otoniel et al., 2008).

Based on the comparison of HTHW generation in India, Vietnam, Switzerland, Mexico, Greece, the UK and Hungary has been described previously, indicating generation HTHW in Semarang higher than in the country of India, Vietnam, Switzerland and Mexico, but is smaller when compared to the generation of HTHW in Greece, England and Hungary. This indicates 


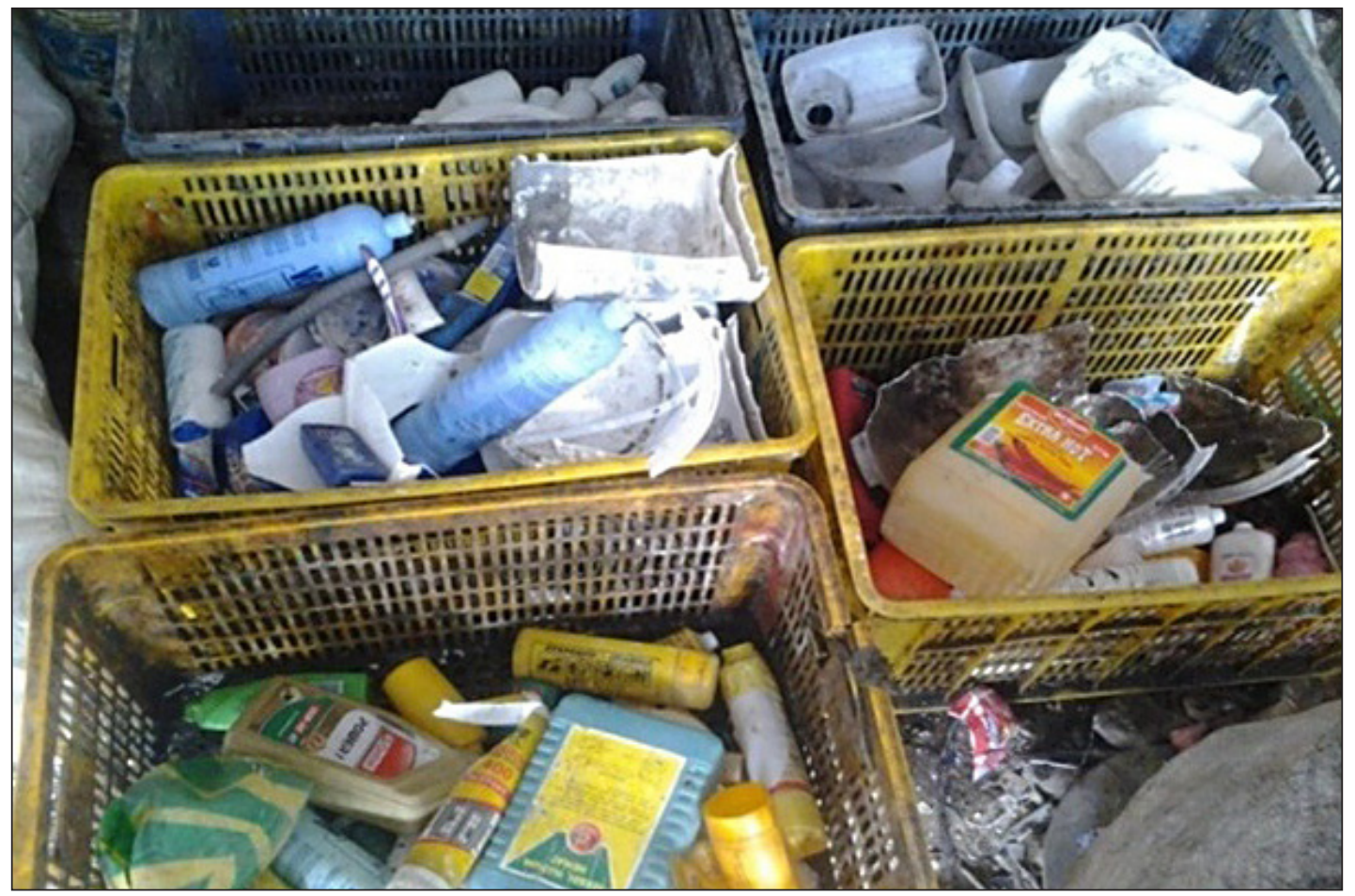

Figure 5. Identify the type and composition HTHW

the diversity of generation HTHW level in each country. In addition to the comparison of from 11 countries, there are few studies that reported the contribution/percentage HTHW in domestic waste, including:

Table 3 shows that the percentage HTHW in Semarang is similar to research done by Tuthill et al (1987) in Massachusetts, USA with a percentage of $5.7 \%$ (Tuthill et al., 1987). But in the results of this study it is lower than that of Ziaee et al (2012) in the city of Tehran that its HTHW percentage reaches $10 \%$ of the domestic waste (Ziaee et al., 2012).

\section{Factors that affect the generation and characteristics HTHW based on respondents characteristics}

Based on the condition respondent characteristics, there are some characteristics that may affect the characteristics and generation of HTHW in Semarang. Respondent characteristics are reflected in some social parameters, including the level of education, occupation, income and life style. These factors will relate to one another for mutual influence. It is also similar to that disclosed by Tchobanoglous et al (1993) which states that the factors which affect the characteristics and solid waste generation is natural and human factors, human factors consist of activity level, lifestyle, and economic conditions.

One of the factors that affect the characteristics and generation of HTHW in Semarang is related to the education level of respondents. Respondents who live in the upper economic strata (the District Pedurungan) most bachelor degree $(30.4 \%)$ and also includes a master (4.6\%) which is higher education, whereas in the middle economic strata (District of Semarang Barat) 7, 0\%, and only $3.9 \%$ in the lower economic strata (District of Semarang Utara). The level of education is important because it can change the perception of knowledge, attitudes and behavior in dealing with garbage (Ramandhani, 2011). Not only that, the level of education will also produce considerations and affect the purchasing power of a product, including products that are hazardous waste which will have implications on the characteristics and HTHW generation.

Someone is going to affect the level of education obtained employment (Atmasari, 2011). The results of interviews with respondents showed that respondents who live in upper economic strata (the District Pedurungan) are largely self-employed (25.7\%), Semarang Barat (20.2\%) and Semarang Utara (19.5\%). The work has a very big role in human life, both in relation to oneself, with others and with society in which he lived. Economically, peo- 
Table 3. Comparison of contribution/percentage HTHW with domestic waste

\begin{tabular}{|c|l|c|c|}
\hline No & \multicolumn{1}{|c|}{ Study } & \% of MSW & References \\
\hline 1 & Tehran & 10 & Th] \\
\hline 2 & Semarang, Indonesia (weight scale) & 5.7 & {$[14]$} \\
\hline 3 & Massachussets, USA & 5.0 & This study \\
\hline 4 & Semarang Indonesia (volume scale) & 3.9 & {$[7]$} \\
\hline 5 & Mexicali & 3.7 & {$[11]$} \\
\hline 6 & Morelia, Meksiko & 1.6 & {$[15]$} \\
\hline 7 & Greenland & 1.2 & {$[7]$} \\
\hline 8 & Cuitzeo, Basin, Meksiko & 1.01 & {$[16]$} \\
\hline 9 & UK & 1.0 & {$[9]$} \\
\hline 10 & Karnataka, India & 0.9 & {$[10]$} \\
\hline 11 & Mekong Delta City, Vietnam & 0.2 & {$[17]$} \\
\hline 12 & Thesaloniki, Yunani & 0.06 & {$[18]$} \\
\hline 13 & Hangzhou, China & 0.05 & \\
\hline
\end{tabular}

ple who work or will earn money that can be used to meet the personal needs of daily (Udin, 2010). The fulfillment of these needs, of course, should not be separated from the product which is hazardous waste.

Self-employed jobs tend to be more open to the environment and receive technological development. The technological development led to the assimilation of information and a strong media advertising to influence someone to buy a product, and one of them is a product which is hazardous waste. Technological developments are also related to product packaging, according Damanhuri (2010) product packaging materials daily necessities will affect the composition of the waste produced, is no exception HTHW (Damanhuri, 2010).

These results correlated with different income levels based on economic strata. On the upper economic strata (sub-district Pedurungan) the average respondent income IDR.3.000.000$5.000 .000,-$ is $15.6 \%$, Semarang Barat $(8.5 \%)$ and Semarang Utara $(1,3 \%)$. The level of education is one of the factors that affect revenue (Putri, 2013). People who have higher levels of education would earn a better income. Education becomes a vehicle that bridges the gap between the level of education that has been achieved with the level of education desired / required to achieve a goal, in addition to the education level of income is also affected by the type of work.

This type of work is also one of the factors that affect revenue (Cahyono, 2006). Education someone very influential on the type of work, if the higher education, the type of work would be higher and it will affect the person's earned income. In addition, the type of work a person will be in accordance with the skills possessed. There- fore, the level of education and skills greatly affect the type of work.

Related to the difference in income based on the economic strata and generation HTHW, different income levels determine the types of homes and settlements to be populated. According to Sumardi \& Hans (1982), there is a correlation between the quality of the housing with the ability to build (which is related to income levels). The higher the level of income, the ability to build quality housing, the better, and vice versa (Sumardi, 1982). It is proved that the revenue (income) community is one of the factors that affect the amount of HTHW generation. Tendensinya, the higher one's income, the more HTHW caused. This is due, among others, to more numerous and diverse activities of life, increases the complete necessities of life, and lifestyle (Dewilda et al., 2014), to determine the composition and HTHW based revenue (economic strata) are expected HTHW management system can be determined according to the precise area targets and problems in the management HTHW can be prevented and it is anticipated as early as possible directly at the source.

Factors that have been previously described, is also on the life style factors (consumer culture) that will continue to thrive in the community. One example is the use of disposable diapers, which is now no longer a luxury, but has become a basic requirement replaces cloth diapers (cloth diapers) because it was considered more practical. The culture of consumerism is a problem and will remain rooted in the community.

HTHW generation in a city will increase from year to year. That is because an increase in quality of life, so that the patterns of consumption will increase as well. Humans will never be satisfied in meeting their needs, the purchasing power of an 
item or food will continue to increase. The increase in consumption pattern that causes waste generated will increase. The number or volume of waste will be proportional to the level of consumption of goods or materials are used in everyday life. Similarly, the type of waste, is highly dependent on the type of material consumed. Based on these descriptions, the factors that affect the generation HTHW in Semarang presented in Figure 6.

Benefits of HTHW generation of data needed to determine the amount of HTHW that must be managed and constituents of the waste management system alternative solutions that efficiently and effectively. The study on data on HTHW generation is the first step done in (Tchobagnolous, 1983). Moreover, the goal is known as the generation HTHW generation forecast HTHW generated for the present and the future and serve as the basis of planning and design management system (Tchobagnolous, 1983).

In managing urban HTHW, not only should the government be active in providing regulatory and handle HTHW, but also takes an active role public awareness and to participate in cooperation with the government in managing the HTHW. Paradigm on the responsibility of managing the waste that is focused on the government to be changed. Another paradigm that must be changed is the garbage fees that are regularly paid by the residents as a reason to remove the responsibility to manage their own waste. The garbage fees can be used as a reason to throw the whole responsibility to officers or city office trash in waste management.

\section{CONCLUSIONS}

1) The analysis by weight showed HTHW generation reached $0.01 \mathrm{~kg} /$ person/day or $5.1 \%$ of total domestic waste. HTHW generation of significant differences indicated by economic levels (upper, middle and lower) as well as the topography of the area in the city of Semarang. In addition, the results of the analysis of generation HTHW by volume can be used as a reference for other cities in developing countries such as Indonesia.

2) The characteristics of HTHW in Semarang consist of corrosive, combustible, poisonous, and infectious. The largest characteristic of HTHW in Semarang is Infectious. The proportion of the order did not differ between the waste produced household groups with middle to upper economic levels and the groups of households with lower economic level. Only the characteristics of the resulting HTHW household groups with the economic level of more diverse kinds of economic level than the middle and lower economic levels.

\section{Acknowledgements}

This study was financially supported by Lembaga Pengelola Dana Pendidikan (LPDP), Ministry of Finance, Indonesia scheme (Contract: PRJ-598/LPDP/2014).

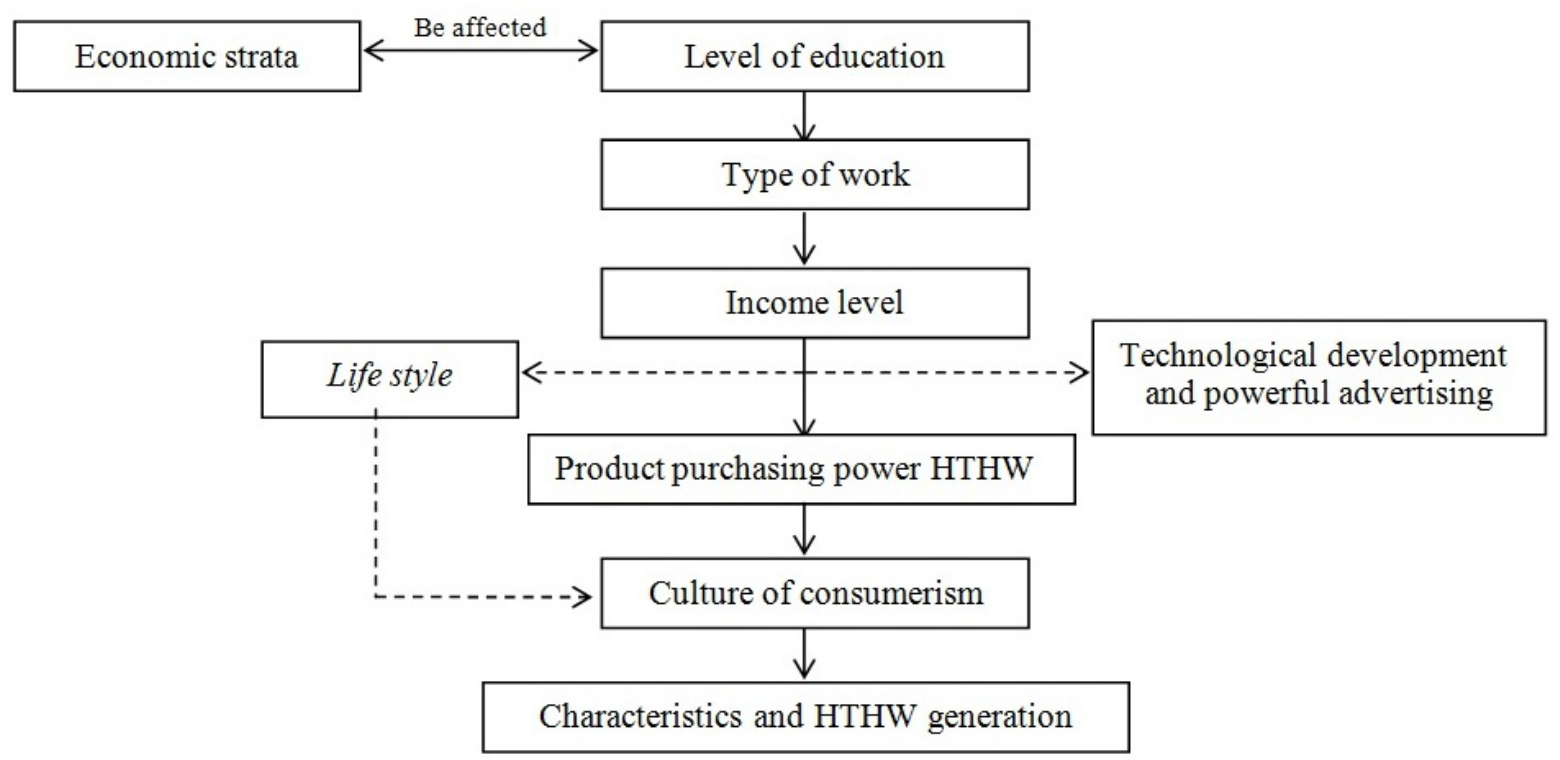

Figure 6. Factors that affect the generation and characteristics HTHW based on respondents characteristics 


\section{REFERENCES}

1. Atmasari, N.N., 2011, The relationship between education level with Main Industry in East Java in 2009. Malang: State Islamic University of Maulana Malik Ibrahim.

2. Burnley, S.J., 2007, A review of municipal solid waste composition in the United Kingdom. Journal Waste Management. 27, 1274-1285.

3. Cahyono, S.A., Nur A.J., Yonki I. 2006. Socioeconomic Characteristics Affecting Household Income pine sap tappers in the village Somagede, Kebumen, Central Java. Journal of Social and Economic Research Forestry. 3,1-18.

4. Damanhuri, E., 2010. College textbooks TL-3104 Solid Waste Management. Bandung: Penerbit ITB.

5. Delgado, O.B., Ojeda-Benitez, S., Marquez, BL., 2007, Comparative Analysis of Hazardous Household Waste in Two Mexican Regions. Journal Waste Management. 27, 792-801.

6. Dewilda, Y., Yeggi, D., Indriyani, Z., 2014, Generation Unit and Domestic Waste Composition Tanah Datar. Journal of Environmental Engineering UNAND, 1:28-33.

7. Eisted, R., Christensen, T.H. 2011, Characterization of Household Waste in Greenland. Journal Waste Management. 31, 1461-1466.

8. Fikri, E., Purwanto., Henna, R.S., 2015, Modelling of Household Hazardous Waste (HHW) Management in Semarang City (Indonesia) by Using Life Cycle Assessment (LCA) Approach to Reduce Greenhouse Gas (GHG) Emissions, Procedia Environmental Sciences. 23, 123-129.

9. Fikri, E., Purwanto., Henna, R.S., 2016. Life cycle assessment of household hazardous waste management options for Semarang City, Indonesia. Int. J. Environment and Waste Management. 17(2), 146-157.

10. Jin, J., Wang Z., Ran S., 2006, Solid waste management in Macao: Practices and challenges. Journal Waste Management. 26, 1045-1051.

11. Lakshmikantha, H., Lakshminarasimaiah N. 2007 , Household Hazardous Waste Generation-Management. Proceeding of The International Conference on Sustainable Solid Waste Management 5-7 September 2007, Chennai, India; 163-168.

12. Ololade, I.A., Adewunmi, A., Ologundudu, A., Adeleye, A., 2009, Effect of Household Waste on Surface and Underground Waters. International Journal of Phisical Science. 4, 22-29.

13. Otoniel, B.D., Liliana, M.B., Francelia, P.G., 2008, Consumption Patterns and Houshold Hazardous Solid Waste Generation in an Urban Settlement in Mexico. Waste Management. 28, 52-56.

14. Papachristou, E., Hadjianghelou, H., Darakas, E., Alivanis, K., Belou, A., Ioannidou D., Para- skevopoulou, E., Poulios, K.., Koukourikou, A., Kosmidou N., Sortikos K. 2009, Perspectives for integrated municipal solid waste management in Thessaloniki, Greece. Journal Waste Management, 29.1158-1162.

15. Putri, A.D., Nyoman, D.S., 2013, Effect of Age, Education, Employment Against Poor Household Income in Rural Bebandem. E-Jurnal EP Unud; 2: 173-180.

16. Rivera, M.M., \& Rivera R.V., 2007, Practical Guide to Thesis and Dissertation Writing. Quezon City, Philippines: Katha Publishing.

17. Ryan T.P., 2013, Sample Size Determination and Power. Hoboiken, New Jersey: John Wiley \& Sons, Inc.

18. Sevilla, C.G., 1990, A Research Primer. Quezon City Philippines: Rex Printing Company. Inc.

19. Stanek, E.J., Tuthill R.W., Willis C., Moore, G.S., 1987, Household Hazardous Waste in Massachusetts. Archives of Environmental Health; 42, 84-86.

20. Sumardi, M., Hans D.E., 1982, Poverty and basic needs. Jakarta: Yayasan Ilmu-Ilmu Sosial Rajawali.

21. Tchobagnolous, G., Theisen H., Vigil, S., 1993, Integrated Solid Waste Management (Engineering Principles and Management Issues). Singapore: McGraw-Hill International Editions.

22. Thanh, N.P., Matsui Y., Fujiwara T. 2010, Household Solid Waste Generation and Characteristic in a Mekong Delta City, Vietnam. Jounal of Environmental Management. 2307-2321.

23. Tuthill, R.W., Edward, J.S., Willis, C., Moore, G.S., 1987, Degree of Public Support for Household Hazardous Waste Control Alternative. American Journal of Public Health (AJPH). 77, 304-306.

24. Udin, K.A., 2010, The relationship between level of education and type of work with community participation in development in Jetis Subdistrict Jaten Karanganyar year 2009/2010. Surakarta: The Faculty of Education University of March Surakarta.

25. Zhuang, Y., Wu, S.W., Wang Y.L, Wu, W.X., Chen, Y.X. 2008, Source separation of household waste: A case study in China. Journal Waste Management. 28, 2022-2030.

26. Ziaee, S., Omrani, G., Agha, M.M.A., Mansouri, N., 2012, Qualitative and Quantitative Examination of Household Hazardous Waste in Tehran. Advances in Environmental Biology. 6, 676-68.

27. Zotos, G., Karagiannidis A., Zampetoglou S., Malamakis A., Antonopoulos I.S., Kontogianni S., Tchobanoglous G. 2009, Developing a holistic strategy for integrated waste management within municipal planning: Challenges, policies, solutions and perspectives for Hellenic municipalities in the zero-waste, low-cost direction. Journal Waste Management; 29,1686-1692. 